\title{
Financial and Non Financial Factors that Influence the Implementation of IFRS
}

\author{
Icih, Siti Rodiah Qolbiah \\ Accounting Department \\ STIE Sutaatmadja Subang \\ icih811@yahoo.com
}

\begin{abstract}
Benefits of IFRS adoption by Indonesia has increased credibility, usefulness and comparability of financial reporting . In fact, the adoption of IFRS, many obstacles. This research aims to determine the financial and non financial factors that affect the implementation of IFRS on 8 companies in Property and Real Estate companies listed in Indonesia Stock Exchange 2010-2013. Financial factors examined in this study are out finance (out debt and out equity), leverage (LEV), foreign revenue (FREV), and size (SZ) . Non financial factors are issue, power distance (PD), and size of public accountant firm(PA).Methods of observation in this study using descriptive statistics with quantitative methods. Sampling selection method used is purposive sampling, The analysis technique used is the technique of multiple regression using SPSS version 20 software. Based on the results of multiple regression test, results showed that partially out debt, out equity, size, and size of public accountant firm does not affect the implementation of the IFRS, while leverage, issue, foreign revenue, power distance affect the implementation of IFRS. Simultaneously variables out finance, leverage, issue, foreign revenue, size, size of public accountant firm and power distance affect the implementation of IFRS.
\end{abstract}

Keywords: IFRS,Out Finance, Foreign Revenue, Power Distance

\section{INTRODUCTION}

The global market has increased very rapidly. The growth of technology, capital and the need to create sources of new revenue unhindered national borders is a key driver for companies entering the global business environment [12]. These objectives can be achieved if the company can provide quality financial statements, one of the requirements is that it can be compared by any users of financial statements in various countries, therefore the necessary harmonization (convergence) international accounting standards (GAAP with IFRS).

Indonesian Institute of Accountants has made the convergence of IFRS Phase 1 consists of three phases: the adoption (2007-2010), the final preparation stage (2011) and the implementation phase (2012). IFRS Convergence Phase 1 produces the Financial Accounting Standards in 2012 which contains $95 \%$ of IFRS in 2009 and 78\% IFRS in 2014 [15]. Based on this it appears that the main purpose of IFRS convergence changes continuously.

Benefits of IFRS adoption by Indonesia has many benefits including increased credibility, usefulness and comparability of financial reporting [8]. In fact, the adoption of IFRS, many obstacles. This is due to the amount of costs to be incurred by the company's investment in technology and information in support of the implementation of IFRS, training costs, a decrease in net income due to changes in accounting methods and the amount of tax to be borne by the company [6]

Factors that affect the application of international accounting standards by Fritz and Lammle [4] consists of National Culture, Provider of Capital, Taxation System, Legal System and Other Influences. These factors can be broadly grouped into financial and non-financial groups.

Based on the above issues, there are few studies related to factors that affect the application of IFRS. Research Arsenos Panagiotis \& Athianos Stergios [12] show that companies obtain financial resources from external parties that do not have a special relationship with the company more motivated to use international accounting standards. Research Izma Fikrotusshohah [17]concluded that there is a difference in the level of earnings management and the relevance of values before and after the full adoption of IFRS. Research Adhitya Wahyu Ramadhan [13]summed up the cultural dimension of the accounting value. Cultural factors have impact on implementation of global accounting standards (IFRS) [19]. Marco at al have researched that IFRS have relationship with the companies' financing structure [20].

The phenomenon of the application of IFRS is also faced by the property industry in Indonesia. As mentioned above that although the application of IFRS provides several benefits at once, but does not guarantee the company directly to apply IFRS. Another thing is the background of this research is the subprime cases that occurred in the United States in 2008. The main issue of the case is the bad loans from the property industry, causing a crisis in many countries. The market value of the property dropped dramatically, so the company went bankrupt. Historical Cost failed to detect a decrease in property value at the time [6]. This prompted the authors chose the company in the field of industrial property. So, the author interested in conducting research entitled "Financial and Non Financial Factors Influence on the Implementation of International Financial Reporting Standard (IFRS)

(Case Study At Property and Real Estate Companies Listed At Indonesian Stock Exchange From 2010-2013)" 
Based on the description of the background above, the identification of issues to be examined in this study are as follows:

1. How does out of debt, out equity, leverage, issue, foreign revenue, size, big-4 accounting firm, and culture, partially has influence on the implementation of IFRS in Property \& Real Estate companies listed on the Stock Exchange in 2010-2013?

2. How does out of debt, out equity, leverage, issue, foreign revenue, size, big-4 accounting firm, and culture, simultaneously has affect the implementation of IFRS in Property \& Real Estate companies listed on the Stock Exchange in 2010-2013?

\section{II. .FACTORS OF FINANCIAL AND NON-FINANCIAL AFFECTING THE APPLICATION OF IFRS}

According to the Financial Accounting Standards [8], the definition of the financial statements is as follows:

The financial statements are part of the financial reporting process. Comprehensive financial statements typically include the statement of financial position (balance sheet) at the end of the period, statement of comprehensive income during the period, changes in equity during the period, cash flow statement for the period, the notes to the financial statements contain a summary of significant accounting policies and other explanatory information.

The preparation of financial statements requires accounting standards. Companies must prepare financial reports that can be understood by all users of financial statements in various countries, so that the company could enter the global business competition. So that financial statements can be understood by users of financial statements in many countries, the required accounting standards are international accounting standards, IFRS for example. IAI has been harmonization between GAAP with IFRS and began to be implemented in the Financial Accounting 2012. Financial Accounting Standards based on IFRS is applied to all companies in various industries including property and real estate.

The definition of property according to Minister of Housing Decree No.05 / KPTS / BKP4N / 1995, Ps 1.A: 4 property is land or building rights and permanent is the object owner and development. Real estate is the land and all permanent improvement thereon including structures, such as buildings, roads, open land, and any other development permanently attached.

IFRS is international accounting standards issued by the International Accounting Standards Board (IASB). The International Accounting Standards drawn up by the four major world organizations, namely the IASB, the Commission of the European Communities (EC), the International Organization of Capital Markets (IOSOC). IASB previously called International Accounting Standards Committee (IASC), an independent agency to formulate accounting standards and become power steering in determining the international accounting standards [7].

According to Ari Pratama [15], IFRS uses Base Principles, namely:

1. More emphasis on interpretation and application of the standard, which should focus on the spirit of the application of these principles.

2. Standard requires an assessment of the substance of the transaction and evaluating whether the accounting presentation reflects economic reality.

3. Requires professional judgment in the application of accounting standards.

IFRS uses fair value in the assessment. Fair value is the amount for an asset that could be exchanged through fair transaction involving parties who wish and have sufficient knowledge [15].If there is no active market value, then it should do the assessment yourself or use the services of appraisers. In addition, IFRS requires disclosure (disclosure) is more both quantitative and qualitative.

IFRS Convergence is one of the agreements the government of Indonesia as a member G20forum, results of the G20 leaders meeting in Washington DC forum, 15 November 2008. In addition, Indonesia is also part of the IFAC (International Federation of Accountants) should be subject to the SMO (Statement Membership Obligation), one of them using IFRS as accounting standards.

As explained previously that IFRS has three main characteristics, namely the principle based, fair value, and more disclosure [15]. Further characteristics are more disclosure in the application of IFRS is based on a checklist of disclosure of financial statements issued by BAPEPAM . In the checklist there are some special information disclosed by the company's property \& real estate, is as follows:

1. Disclosure of the carrying value of inventory by classification:
a. land;
b. Building; and
c. Building in Progress.

2. Capitalization and cost allocation method development projects Real Estate.

a. The element of cost capitalization to Real Estate development projects;

b. Elements allocated as an expense the cost of the project;

c. Cost allocation method that has been capitalized to each unit Real Estate;

d. The revised fees and reallocates due to fundamental changes in the estimates; and

e. The element of cost to be recognized as an expense when incurred.

Factors that affect the application of international accounting standards by Fritz and Lammle [4] consists of National Culture, Provider of Capital, Taxation System, Legal System and Other Influences. These factors can be grouped into financial and non-financial groups are described below:

A. Financial 
a. Out Finance (The proportion of outsider equity and outsider debt).

i. out equity

The proportion of ordinary and preference share capital held by outsiders to a company to total share capital. As outsider equity was taken, the proportion of equity (the number of ordinary and preference shares) belongs to outsiders who do not have privilege rights to the company: like individual investors, companies or institutions. On the contrary, insiders are the number of individual, banks or other companies (which are related with the company, for example associated companies or in the case of a bank, an institution that had provided the company with a loan or in the case of the individual, the initial ownership or ownerships.

ii. out debt

Outsider debt was defined as the proportion of the long-term debt owned by outsiders to the company in comparison to all long-term debt of the company; more specifically, outsiders are the number of capital public who are the source of finance for the companies' debt. On the other hand, insider debt was determined as the long-term debt a company has borrowed from a bank, like a loan or an overdraft, provisions for employee benefits, other provisions, leasing obligations, provisions for employee retirement or redundancy compensation, deferred tax, deferred income, loans from the parent company or liabilities to associated companies, long-term trade payable and other liabilities.

b. Foreign Revenue (FR) is the proportion of a company's foreign revenue to total sales revenue.

c. Size is log of market capitalization (Indonesian currency converted to millions of dollars at government fixed exchange rate).

d. Leverage is Total liabilities as a proportion of market value of equity (market capitalization at financial year end).

B. Non-Financial

a. Culture (Power Distance)

b. Issue (refers in case that the company had within the year an issue of public debt or public equity. 1 when the company had within the year an issue of public debt or public equity)

c. Big 4 (The company uses a Big 4 auditor. Dummy variable coded 1 = uses a Big 4 audit firm, 0 otherwise)

\section{Source: Fritz and Lammle [4]}

Nobes [3] studied the reasons for differences in accounting systems in various countries. He found in one country might have more than one accounting standard, one standard for companies listed on the stock exchange, and the other for companies that are not listed on the stock exchange. Companies that have a majority of the shares of financial resources requires presentation of financial statements more than a company that has a major source of loans due regard to the protection of investors. Furthermore, according Nobes [3], which referred to the "insiders" are governments, banks, and other family members who have a special relationship with the company and the long-term, while "outsiders" are not members of the board of directors and has no special relationship with the company. Understanding of the "insider" and "outsider" This is very important as well as an understanding of the share capital and loans. It is very influential on the accounting standards used in preparing the financial statements. If the financial resources of the company's creditors, preparation of financial statements more emphasis on profits and taxes. Meanwhile, if the company's financial resources derived from the capital market, the financial statements are very concerned that relevant and reliable information about the performance and financial condition of the company and help investors in making decisions.

Furthermore Nobes [3] classifies the stock market into groups A and B. Group A is a capital market where "outsider financiers" are the main source of corporate finance. Group B is a capital market where the major financial resources obtained from the company "insiders financiers". Based on this it can be concluded that the accounting system of a country or a company depends on the source of funding. Indonesian capital market is included in group B, where there are accounting standards for listed companies and other accounting standard for companies that are not listed on the stock exchange. Based on this, it can be hypothesized:

$\mathrm{H} 1$ = Out Debt has a significantly positive effect on the application of IFRS

$\mathrm{H} 2$ = Out Equity has a significantly positive effect on the application of IFRS.

Leverage is the proportion of total liabilities and equity. High degree of leverage have negative impact for investors, thus requiring the disclosure of financial statements more especially if the outsider is the majority shareholder.

Results of research Arsenos et al [12] in companies listed on the stock Greece showed that companies using international accounting standards tend to have lower leverage. From the description, then the hypothesis is:

$\mathrm{H} 3$ = Leverage has a significantly negative effect on the application of IFRS.

Issue defined the company within the year had an issue of public debt or public equity. Issue occurs if the company issuing public debt or common equity in the accounting year [12]. With the issuance of shares or debt to the public, then the company's financial statements will become a source of information that is needed by the public. Therefore, the company will be identical to the application of international accounting standards (IFRS) for their demands for more disclosure in reporting.

Rizfan research results [18] supports the above opinion, that the companies that issue public debt or equity general tend to use IFRS. Then the hypothesis formulated is: 
$\mathrm{H} 4$ = Issue has a significantly positive effect to the application of IFRS.

Arsenos et al [12] in his journal, define foreign revenue as the proportion of a company's foreign revenue to total sales revenue, ie the proportion of the company's revenue to total revenue overseas. If the proportion of overseas revenue amount is significant, the company will make more disclosures in its financial statements because it is different, as well as the application of IFRS.

Arsenos et al [12] have examined the companies listed on the stock exchange Greece in 2004-2005. The results showed that companies with overseas earnings are likely to apply IFRS. So that the hypothesis can be formulated as follows:

H5 = Foreign revenue has a significantly positive effect on the application of IFRS

Size (size) is a scale which can be classified on the size of companies according to various ways, among others: total assets, sales, log size, the stock market value, market capitalization, and others that are all highly correlated. Largesized companies that do a lot more disclosure as applied under IFRS.

H6 = Size has a significantly positive effect on the application of IFRS

International public accounting firm or big-4 can offer clients their credibility in the financial statements, because of their experience in the international accounting standards around the world. While companies strive to improve the relevance in their financial statements. This is what requires them to use international standards.

Rizfan Rahman [18] found that there is a positive relationship between the application of IFRS with the use of Big-4 accounting firm, then the hypothesis is:

H7 = KAP Big-4 has a significantly positive effect on the application of IFRS

Hofstede conduct comprehensive research in more than fifty countries to study the structures of the culture of each country of individualism / collectivism, power distance width / short power distance, uncertainty avoidance strong / weak uncertainty avoidance, and masculinity / femininity. One of the indicators studied Hofstede culture is the power distance [2].

Based on the results of research Hofstede, Gray proposes a framework that links between culture and accounting. According to Gray, power distance negatively affect professionalism. This is due to more professionalism may be acceptable in a society (in this case) with a distance smaller keuasaan where people at various levels of power feel less threatened and more ready to trust others [7]. Research Adhitya Wahyu in 2012[13] identifies the power distance with low levels of education and higher education From the above description, it can be formulated hypotheses as follows:

$\mathrm{H} 8=$ Cultural has a significantly negative effect on the application of IFRS

\section{RESEARCH METHODOLOGY}

This study was a quantitative research analyzed using descriptive statistics, the statistics used to analyze data to describe or depict the data that has been collected as it is without intending to apply to general conclusions or generalizations [9].

The population in this study is in the field of property \& real estate listed on the Indonesia Stock Exchange (BEI). The study period of 4 years, ie 2010-2013 with a sample of 32 companies.

Sample selection technique used is purposive sampling, ie sampling technique with a certain considerations [9].

Classical assumption made is Normality Test, Test Multicollinearity, heterocedastity Test, and Test Autocorrelation.

Multiple linear regression is intended to determine the linear relationship between several independent variables commonly called $\mathrm{X} 1, \mathrm{X} 2, \mathrm{X} 3$, and so on with the dependent variable is called $\mathrm{Y}$. The model equation is as follows

$$
\begin{aligned}
& \mathrm{Y}=\mathrm{a}+\beta 1 \mathrm{X} 1++\beta 4 \mathrm{X} 4 \beta 3 \mathrm{X} 3 \beta 2 \mathrm{X} 2+++\beta 7 \mathrm{X} 7 \beta 6 \mathrm{X6} \\
& \beta 5 \mathrm{X} 5+++\beta 8 \mathrm{X} 8 \beta 8 \mathrm{X} 9 \mathrm{e}
\end{aligned}
$$

Information :

$$
\begin{aligned}
& \mathrm{Y}=\text { Application of IFRS } \\
& \mathrm{a}=\text { Constant } \\
& \beta 1-\beta 8 \text { regression coefficient }= \\
& \mathrm{X} 1=\text { Out Debt } \\
& \mathrm{X} 2=\text { Out Equity } \\
& \mathrm{X} 3=\text { Leverage } \\
& \mathrm{X} 4=\text { Issue } \\
& \mathrm{X} 5=\text { Foreign Revenue } \\
& \mathrm{X} 6=\text { Size } \\
& \mathrm{X} 7=\text { KAP Big- } 4 \\
& \mathrm{X} 8=\text { Culture } \\
& \mathrm{e}=\text { error (bully) }
\end{aligned}
$$

The statistical test used was the $\mathrm{F}$ test and $\mathrm{t}$ test. The statistical test $\mathrm{F}$ basically indicates whether all the independent variables defined in the model have influence together on the dependent variable. Simultaneously, hypothesis testing is done by using the F-test. The t-test was conducted to determine the effect of variable $\mathrm{X}$ (independent) against vabiabel $\mathrm{Y}$ (dependent) partially. How to do a t-test is to compare the significance of the $t$ with the provisions. If significance $<0.05$ so $\mathrm{Ha}$ is received and if the significance of $>0.05$ then $\mathrm{Ha}$ is rejected as well by comparing the statistical value $t$ with $t$ table. If the statistical value of $\mathrm{t}$ test $>\mathrm{t}$ table so $\mathrm{Ha}$ is received while the value statistikt $<\mathrm{t}$ table then Ha rejected.

To simplify the explanation above, the operating tables were drawn following operations (see Table I) 
TABLE I. VARIABLE OPERATIONALIZATION

\begin{tabular}{|c|c|c|c|c|}
\hline Variable & Definition & $\begin{array}{c}\text { Sub } \\
\text { Variable }\end{array}$ & Indicator & Scale \\
\hline \multirow[t]{2}{*}{$\begin{array}{l}\text { Out } \\
\text { Finance }\end{array}$} & \multirow[t]{2}{*}{$\begin{array}{l}\text { Theproporti } \\
\text { onofoutsider } \\
\text { equityandout } \\
\text { siderdebt }\end{array}$} & Out $\operatorname{debt}\left(\mathrm{X}_{1}\right)$ & $\begin{array}{l}\text { The proportion of long term } \\
\text { debt held by outsiders to total } \\
\text { long-term debt. }\end{array}$ & Ratio \\
\hline & & $\begin{array}{l}\text { Out } \\
\text { equity }\left(\mathrm{X}_{2}\right)\end{array}$ & $\begin{array}{l}\text { The proportion of ordinary } \\
\text { and preference share capital } \\
\text { held by outsiders to company } \\
\text { to tota lshare capital }\end{array}$ & Ratio \\
\hline $\begin{array}{l}\text { Leverage( } \\
\left.\mathrm{X}_{3}\right)\end{array}$ & $\begin{array}{l}\text { Total } \\
\text { liabilities as } \\
\text { a proportion } \\
\text { of market } \\
\text { value of } \\
\text { equity(mark } \\
\text { et } \\
\text { capitalizatio } \\
\mathrm{n} \text { at financial } \\
\text { year end) }\end{array}$ & & $\frac{\text { Total Liabilities }}{\text { Total Ekuitas }}$ & Ratio \\
\hline Issue $\left(\mathrm{X}_{4}\right)$ & $\begin{array}{l}\text { The } \\
\text { company } \\
\text { had within } \\
\text { the year an } \\
\text { issue of } \\
\text { public debt } \\
\text { or public } \\
\text { equity }\end{array}$ & & $\begin{array}{l}1=\text { if issuing shares / bonds to } \\
\text { the public } \\
0=\text { otherwise issue shares / } \\
\text { bonds to the public. }\end{array}$ & Dummy \\
\hline $\begin{array}{l}\text { Foreign } \\
\text { revenue(X } \\
\text { 5) }\end{array}$ & $\begin{array}{l}\text { The } \\
\text { proportion } \\
\text { of a } \\
\text { company's } \\
\text { foreign } \\
\text { revenue to } \\
\text { Total sales } \\
\text { revenue }\end{array}$ & & $\frac{\text { Export sales }}{\text { Total sales }}$ & Ratio \\
\hline 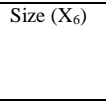 & $\begin{array}{l}\text { Log of } \\
\text { market } \\
\text { capitalizatio } \\
\mathrm{n}\end{array}$ & & $\begin{array}{l}\text { The number of shares } \\
\text { outstanding multiplied by the } \\
\text { stock market price. }\end{array}$ & Ratio \\
\hline $\begin{array}{l}\text { KAPBig-4 } \\
\left(\mathrm{X}_{7}\right)\end{array}$ & $\begin{array}{l}\text { KAP has a } \\
\text { major } \\
\text { competitive } \\
\text { accounting } \\
\text { technical } \\
\text { approach } \\
\text { and } \\
\text { reputation } \\
\text { enhance } \\
\text { their ability } \\
\text { to be more } \\
\text { skilled in the } \\
\text { use of } \\
\text { international } \\
\text { standards. }\end{array}$ & & $\begin{array}{l}\text { 1= If using KAP Big } 4 \\
0=\text { If not using KAP Big } 4\end{array}$ & Dummy \\
\hline $\begin{array}{l}\text { Culture } \\
\left(\mathrm{X}_{8}\right)\end{array}$ & $\begin{array}{l}\text { Culture in } \\
\text { the society } \\
\text { has } \\
\text { institutional } \\
\text { consequence } \\
\mathrm{s} \text { as a } \\
\text { reflection of } \\
\text { the system's } \\
\text { behavior in } \\
\text { the } \\
\text { community. } \\
\text { (Adhitya } \\
\text { Revelation, } \\
\text { 2012) }\end{array}$ & $\begin{array}{l}\text { Hofstede } \\
\text { dimensions } \\
\text { of cultural } \\
\text { values: } \\
\text {. power } \\
\text { distance }\end{array}$ & $\begin{array}{l}\text { - The ratio of employees with } \\
\text { low education with highest } \\
\text { educated employees. }\end{array}$ & Ratio \\
\hline $\begin{array}{l}\text { IFRS } \\
\text { Implement } \\
\text { ation }\left(\mathrm{Y}_{1}\right)\end{array}$ & $\begin{array}{l}\text { Implementat } \\
\text { ion of a } \\
\text { gradual } \\
\text { convergence } \\
\text { of IFRS } \\
\text { standards. }\end{array}$ & & $\begin{array}{l}\text { The three main features: * } \\
\text { - Principle Based } \\
\text { - Fair Value } \\
\text { - More Disclosure }\end{array}$ & Ratio \\
\hline
\end{tabular}

a. Source: Data are processed

\section{RESULTS}

This study shows the significant value $(0.007)$ is less than 0.05 , then out of debt, out equity, leverage, issue, foreign revenue, size, KAP Big-4, and cultures together a significant effect on the application of IFRS. When comparing the value of $F$ test with $F$ table value is known that the value of $F$ test (3.669) is greater than the value of F table (2.32) so it can be concluded that out of debt, out equity, leverage, issue, foreign revenue, size, KAPBig-4, culture simultaneously affect the application of IFRS. Partial assay described in the table below

TABLE II. SignificAnt PARTIAL TeSt Results Coefficients $^{\mathrm{a}}$

\begin{tabular}{|l|l|l|l|l|l|}
\hline \multicolumn{1}{|c|}{ Model } & \multicolumn{2}{|c|}{$\begin{array}{c}\text { Unstandardized } \\
\text { Coefficients }\end{array}$} & $\begin{array}{c}\text { Standardi } \\
\text { zed } \\
\text { Coefficient } \\
\text { s }\end{array}$ & T & Sig. \\
\cline { 2 - 4 } & \multicolumn{1}{|c|}{$\boldsymbol{B}$} & Std. Error & Beta & & \\
\hline (Constant) & 1,806 &, 706 & & 2,559 &, 018 \\
Out Debt &,- 048 &, 124 &,- 068 &,- 389 &, 701 \\
Out Equity &,- 003 &, 001 &,- 452 & 0,658 &, 054 \\
Leverage &,- 001 &, 001 &,- 325 & 1,867 &, 038 \\
Issue &, 008 &, 060 &, 021 & 2,130 &, 048 \\
Foreign Revenue & 9,917 & 3,103 &, 532 & 3,196 &, 004 \\
Size &,- 079 &, 058 &,- 224 & $-1,366$ &, 185 \\
KAP Big-4 &,- 236 &, 075 &,- 570 &,- 149 &, 084 \\
Culture &,- 024 &, 060 &,- 063 & 2,401 &, 042 \\
\hline
\end{tabular}

According to the table above, the regression equations formed is as follows:

$$
\mathrm{Y}=1,806-0,048 \mathrm{X} 1-0,003 \mathrm{X} 2-0,001 \mathrm{X} 3+0,008 \mathrm{X} 4+9,917 \mathrm{X} 5-
$$

0,079X6- $0,236 \times 7-0,024 X 8$

On the development of the first hypothesis has been mentioned that the out debt positive effect on the application of IFRS. The results showed that out of debt does not significantly influence the implementation of IFRS as seen from the significant value (0.701) above or greater than 0.05 . Comparison of t-test value with t table also shows that out of debt does not affect the application of the IFRS where the value t test (-0389) is smaller than t-table (1.71387) It so it can be concluded that the first hypothesis is rejected. From the available data, only $28.12 \%$ long-term liabilities owned by the "outsider" and the rest is owned by "insider". Companies communicate with creditors via the channel of personal information, so it felt less need to apply IFRS. This result does not correspond with the results of research conducted Arsenos et al [12].

The results showed that out equity does not significantly influence the implementation of IFRS as seen from the significant value $(0,054)$ above or greater than 0.05 . Comparison of t-test value with t table also shows that out equity does not affect the application of the IFRS where the value $t$ test $(0658)$ is smaller than t-table (1.71387). It can be concluded that the second hypothesis is rejected. 
Data results showed $59.37 \%$ of its shares owned by the "outsider" but does not affect the application of IFRS means that the company even though the proportion of its shares were held by the public, not necessarily going to do a lot more disclosure as applied in the IFRS. Sample research only stock market listing in Indonesia, so that the majority of shareholders "outsider" is an Indonesian investor who is generally a small investor. So policy is determined by management, including policy on the application of IFRS. These results are consistent with research conducted Wilujeng Anisa Dwi [11] found no effect of public shareholding (out equity) on the property \& real estate companies listed on the Stock Exchange.

The results showed that leverage significant negative effect on the application of IFRS as seen from the significant value $(0,038)$ below or less than 0.05 . Comparison of t-test value with $\mathrm{t}$ table also shows that the leverage effect of the application of IFRS where the value t test (1867) is greater than t-table (1.71387). It can be concluded that the third hypothesis is accepted.

Data sample study showed that $84.38 \%$ of the sample had a leverage level above $50 \%$. The level of its high leverage to encourage companies to make more disclosures with respect to the company's efforts to reduce the level of leverage, so it remains to be trusted by investors. More disclosure is one sign the application of IFRS.

The results showed that the issue of positive significant effect to the application of IFRS as seen from the significant value $(0.048)$ under or less than 0.05 . Comparison of t-test value with $\mathrm{t}$ table also shows that the issue affect the application of the IFRS where the value $t$ test $(2.130)$ is greater than t-table (1.71387). It can be concluded that the fourth hypothesis is accepted.

When companies do issue or the issuance of shares and bonds, it means more capital flows outside investors that flows into the company. In this category of disclosure of the company should be increased because of the "reader" annual report from outsiders continue to rise, while they do not have the internal resources to get the company's performance report [12]. As a result, international standards (IFRS) are more likely to be adopted by companies that do issue.

The results showed that foreign revenue positive significant effect on the adoption of IFRS, as seen from the significant value (0.004) under or less than 0.05 . Comparison of t-test value with $t$ table also shows that foreign revenue affect the application of IFRS where the value t test (3196) is greater than t-table (1.71387). It can be concluded that the fifth hypothesis is accepted.

Based on research Zarzeski [1] in Arsenos et al [12], corporations whose income largely from foreign income is generally a company that trades on the open market are more likely to adopt international standards (IFRS).

Size no significant negative effect on the application of IFRS as seen from the significant value $(0.185)$ above or greater than 0.05 . Comparison of t-test value $(-1.366)$ is smaller than $t$ table (1.71387). So we can conclude that the sixth hypothesis is rejected.
These results indicate that even very large companies would not be able to quickly implement IFRS. This is likely due to the transition to IFRS involves various costs, both direct costs and indirect costs [16].

This result is unable to support research Tarca [5] in Novita Indrawati [16] who found positive evidence that the tendency to adopt IFRS voluntarily increases with the size (size) of the company.

KAP big-4 no significant negative effect on the application of IFRS as seen from the significant value $(0,084)$ above or greater than 0.05 . Comparison of t-test value with $t$ table also shows that big KAP-4 had no effect on the application of IFRS in which the value of t-test $(-0.149)$ is smaller than t-table (1.71387). It can be concluded that the hypothesis is rejected seventh. Data sample KAP study showed that the use of the big-4 only $25 \%$ of the existing data.

\section{CONCLUSIONS AND RECOMMENDATIONS}

Based on the analysis of data and discussion that has been stated previously, it can be concluded that out of debt had no significant effect positively to the implementation of IFRS, out equity is not positive significant effect on the implementation of IFRS, leverage significant negative effect on the implementation of IFRS, issue positive significant effect on the application IFRS, foreign revenue positive significant effect on the implementation of IFRS, the size is not positive significant effect on the implementation of IFRS, big KAP-4 had no significant effect positively on the implementation of IFRS and culturally significant negative effect on the application of IFRS.

Simultaneously, the results of this study showed a significant effect of out finance (out of debt and out equity), leverage, issue, foreign revenue, foreign listings, size, KAP big-4, and culture affect the application of the IFRS company's property \& real estate listed on the Stock Exchange.

Advice can be given is the first, property \& real estate companies into the sample needs to increase the level of application of IFRS for the results of studies showing that the rate of adoption of IFRS is still relatively low, not to place such a case subprime. Second, future research should also add an indicator of cultural variables, such as individualism, uncertainty avoidance, and masculinity. Third, further researchers add indicators IFRS implementation in a company. So the assessment of the implementation of IFRS becomes more accurate and clear.

\section{REFERENCES :}

[1] Zarzeski, M., Spontaneous Harmonization Effects of Culture and Market Forces on Accounting Disclosure Practices, Accounting Horizons, Vol. 10, No. 1.1996.

[2] Gray, S.J., Towards a theory of cultural influences on the development of accounting systems internationally, Abacus, Vol. 24,1998.

[3] Nobes, C.W., Towards a General Model of the Reasons for International Differences in Financial Reporting, Abacus, Vol. 34, No. 2. 1998.

[4] Fritz, S., and Lammle, C., The International Harmonization Process of Accounting Standards, Ekonomiska Institutionen Linkoping. 2003.

[5] Tarca, A., International Convergence of Accounting Practices: Choosing Between IAS and US GAAP, Journal of International Financial Management and Accounting, Vol. 15, No. 1.2004. 
[6] Sonoto, John F. . Isu global konvergensi IFRS: Masalah Pengukuran Menggunakan Fair Value Accounting. Jurnal Akuntansi Kontemporer, Vol.2 No.2, Juli 2010

[7] Frederick D.S. Choi, Gary K.Meek. Akuntansi Internasional. Salemba Empat.2010.

[8] Kurniawan, Dudi M.,Kompas 6 Mei 2010.

[9] Sugiyono, Metode Penelitian Kuantitatif Kualitatif, Alfabeta,2010

[10] Ikatan Akuntan Indonesia. Standar Akuntansi Keuangan.2012

[11] Anisa, Wilujeng Dwi, Pengaruh Likuiditas, Profitabilitas, Ukuran Perusahaan, Dan Kepemilikan Saham Publik Terhadap Pengungkapan Laporan Tahunan. Skripsi. Fakultas Ekonomi Universitas Negeri Semarang.2011.

[12] Arsenos and Athianos, Use of International Accounting Standards and Source of Finance: the Case of Greek Companies Listed in the Athens Stock Exchange, International Research Journal of Finance and Economics. ISSN1450-2887.2011.

[13] Ramadhan, Adhitya Wahyu,. Pengaruh Dimensi Nilai Budaya Terhadap Dimensi Nilai Akuntansi.Skripsi. Fakultas Ekonomi dan Bisnis. Universitas Dipenogoro,2011.

[14] Keputusan Ketua Badan Pengawas Pasar Modal Dan Lembaga Keuangan Nomor: Kep-347/BL/2012

[15] Pratama, Arie.. Akuntansi Keuangan Sesuai Standar Akuntansi Keuangan Terkini. Bandung.2014

[16] Indrawati, Novita,Pengaruh Karakteristik Perusahaan Terhadap Adopsi Sukarela Internationalfinancial Reporting Standards di Indonesia. Jurnal Akuntansi, Vol. 2, No. 2, April 2014 : 114-126. ISSN 2337-4314 2014.

[17] Fikrotusshohah, Izma.. Analisis Kualitas Informasi Akuntansi Sebelum dan Sesudah Adopsi Penuh International Financial Reporting Standard (IFRS).Skripsi. Sekolah Tinggi Ilmu Ekonomi Sutaatmadja Subang,2014.

[18] Rahman, Rizfan. Analisis Faktor-Faktor Yang Mempengaruhi Penerapan IFRS. Skripsi. Sekolah Tinggi Ilmu ekonomi Sutaatmadja,2014.

[19] Nurunnabi, Mohamad.,The Impact of cultural factors on the implementation of global accounting standards (IFRS) in a developing country, Advances in Accounting, Vol.31, Issue 1, June 2015, page 136149.

[20] Marco Aurelio dos Santos at al, Adoption of the International Financial Reporting Standards (IFRS) on companies' financing structure in emerging economies, Finance Research Letters, Volume 16, February 2016, page 179-189. 